Managing Yourself 


\section{Titles in the series}

\section{Barbara Scammell: Communication Skills}

Communication in society

The communications continuum: forms and skills

The communications continuum: coaching and counselling

Planning and organising

Staffing

Co-ordinating

Communication in nurse management at the point of service delivery

Communication in nurse management in different areas of medical care

\section{Verena Tschudin with Jane Schober: Managing Yourself}

'Know thyself'

Valuing yourself

Motivating yourself

Asserting yourself

Stressing yourself

Supporting yourself

Celebrating yourself

Your career - making the choices

\section{Sheila Marson (ed.): Managing Others}

The science and function of management

Team building: a practical approach

Leadership

Creating a climate for learning

Quality and its control

\section{Annabel Broome: Managing Change}

Principles of complex change

Leadership and creating change from within

Imposed change

The nurse as a change agent

Identifying training and development needs

Appendix A: Health of the organisation questionnaire

Appendix B: Role effectiveness profile - tool for self-assessment

\section{Diana Sale: Quality Assurance}

An introduction to quality assurance

Standards of care

Quality assurance measures - performance. Nursing audit

Quality assurance measures - performance. Quality patient care scale

Quality assurance measures - performance. Monitor - an index of the quality of nursing care

Quality circles

Measuring outcome standards - using a computerised nursing system (Excelcare)

\section{Financial Budgeting}

(in preparation) 


\section{Managing Yourself}

Verena Tschudin

with Jane Schober

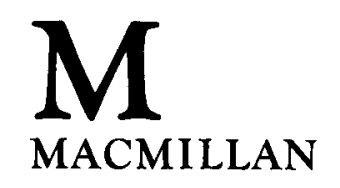


(C) Verena Tschudin (Chapters 1-7) and Jane Schober (Chapter 8) 1990

All rights reserved. No reproduction, copy or transmission of this publication may be made without written permission.

No paragraph of this publication may be reproduced, copied or transmitted save with written permission or in accordance with the provisions of the Copyright Act 1956 (as amended), or under the terms of any licence permitting limited copying issued by the Copyright Licensing Agency, 33-4 Alfred Place, London WCIE 7DP.

Any person who does any unauthorised act in relation to this publication may be liable to criminal prosecution and civil claims for damages.

First published 1990

Published by

MACMILLAN EDUCATION LTD

Houndmills, Basingstoke, Hampshire RG21 2XS

and London

Companies and representatives

throughout the world

British Library Cataloguing in Publication Data

Tschudin, Verena

Managing Yourself.

I. Medicine. Nursing. Management

I. Title II. Schober, Jane E. III. Series

610.73'068

ISBN 978-0-333-48431-9

ISBN 978-1-349-10622-6 (eBook)

DOI 10.1007/978-1-349-10622-6 


\section{Contents}

Acknowledgements

Preface

Prologue: The dream ...

Chapter 1 'Know thyself'

Awareness

Awareness of the body

Awareness of the senses

Awareness of the environment

Awareness of temperament

Awareness of other people

References

Chapter 2 Valuing yourself

Personal values

Professional values

References

Chapter 3 Motivating yourself

Motivation

Mistakes and failures

References

Chapter 4 Asserting yourself

Aggression or assertion?

Aspects of behaviour

Are you assertive?

References

Chapter 5 Stressing yourself

Stress and stressors

Stress

Stressors

Coping with stress

References

Chapter 6 Supporting yourself

Support

Education and training

Mentors

Co-counselling

Counsellors

Support groups

How are you supporting yourself?

References

Chapter 7 Celebrating yourself

Celebrating

Affirming

Remembering

Expecting

References 
Chapter 8 Your career - making the choices by Jane Schober

What is a career?

Making career decisions

Personal goal-setting

Planning your career - the choices

Conclusion

Sources of career information

Useful addresses

References

Index 


\section{Acknowledgements}

The author would like to thank Jane Schober very particularly for writing the chapter on career choices; special thanks also to Margaret Wellings, for turning yet another set of scrap papers into a manuscript; and to Jill Baker, for helping and encouraging this project to completion.

The author and publishers would like to thank the following photographic sources:

Sally and Richard Greenhill

The Photo Co-op

Topham Picture Library

Every effort has been made to trace all the copyright holders but if any have been inadvertently overlooked the publishers will be pleased to make the necessary arrangement at the first opportunity. 


\section{Preface}

'Management' has become one of those magic words: as long as you manage you're OK.

Management usually means 'other people'. In this book it means yourself. And this is where the problem starts. We generally know how to manage others. We know what they should do, how they should behave, how they should do their job, look after their children, deal with their colleagues, and so on. But to apply these same principles to ourselves is not nearly as easy.

This book starts with the principle that 'charity begins at home'. This doesn't mean indulging ourselves in all sorts of excesses: it means on the contrary a kind of discipline which doesn't shrink away from looking at the good and bad in us, the strengths and weaknesses, the helpful and unhelpful, the possible and impossible parts of ourselves. This can sometimes be daunting. It is not easy to face up to the darker side of the reality that we are, or make choices which lead us into the unknown. But it is often there that discoveries are made which can and will transform our lives.

As a nurse you are first of all a person. And although addressed to you as a nurse, this book looks at you as a person behind the uniform. It is meant for you the person, to be more effective in your work as a nurse: to manage yourself and others better.

Verena Tschudin January 1990 